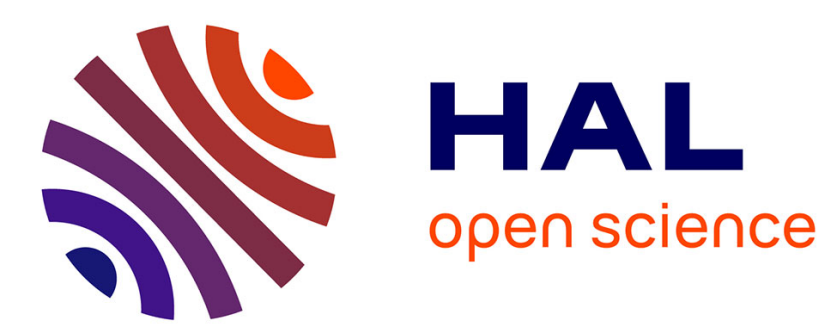

\title{
Evidence of the radioactive fallout in France due to the Fukushima nuclear accident
}

\author{
O. Evrard, P. van Beek, D. Gateuille, V. Pont, I. Lefevre, B. Lansard, P.
}

Bonte

\section{- To cite this version:}

O. Evrard, P. van Beek, D. Gateuille, V. Pont, I. Lefevre, et al.. Evidence of the radioactive fallout in France due to the Fukushima nuclear accident. Journal of Environmental Radioactivity, 2012, 114, pp.54-60. 10.1016/j.jenvrad.2012.01.024 . hal-00984554

\section{HAL Id: hal-00984554 \\ https://hal.science/hal-00984554}

Submitted on 26 May 2020

HAL is a multi-disciplinary open access archive for the deposit and dissemination of scientific research documents, whether they are published or not. The documents may come from teaching and research institutions in France or abroad, or from public or private research centers.
L'archive ouverte pluridisciplinaire HAL, est destinée au dépôt et à la diffusion de documents scientifiques de niveau recherche, publiés ou non, émanant des établissements d'enseignement et de recherche français ou étrangers, des laboratoires publics ou privés. 


\section{Evidence of the radioactive fallout in France due to the Fukushima nuclear accident}

Olivier Evrard ${ }^{1,}$, Pieter Van Beek ${ }^{2}$, David Gateuille ${ }^{1}$, Véronique Pont ${ }^{3}$, Irène Lefèvre $^{1}$, Bruno Lansard ${ }^{2}$, Philippe Bonté ${ }^{1}$

${ }^{1}$ Laboratoire des Sciences du Climat et de l'Environnement (LSCE/IPSL), Unité Mixte de Recherche 8212 (CEA/CNRS/UVSQ), Centre de Recherche du CNRS, Avenue de la Terrasse, F-91198 Gif-sur-Yvette Cedex, France

${ }^{2}$ LEGOS, Laboratoire d'Etudes en Géophysique et Océanographie Spatiales

(CNRS/CNES/IRD/UPS), Observatoire Midi Pyrénées, 14 avenue Edouard Belin, F-31400 Toulouse, France

${ }^{3}$ LA, Laboratoire d'Aérologie (CNRS/UPS), Observatoire Midi Pyrénées, 14 avenue Edouard Belin, F-31400 Toulouse, France

*Corresponding author. E-mail address: olivier.evrard@lsce.ipsl.fr. Telephone:

+33/1/69.82.35.20. Fax: +33/1/69.82.35.68.

Keywords: Fukushima accident; radioactive fallout; radioiodine; radiocesium; France.

\section{Highlights}

- Artificial radionuclides emitted by Fukushima power plant accident were detected in environmental samples collected in France

- Radioactivity measurements on air filters obtained at the highest altitude in France

- ${ }^{131}$ I detected in grass, soil and sediment collected between 30 March - 12 April

- ${ }^{134} \mathrm{Cs}$ detected in grass collected between 31 March - 10 April

- Total ${ }^{134} \mathrm{Cs}$ input to grass of $2 \mathrm{~Bq} \mathrm{~m}^{-2}$ ( $\sim 400$ times lower than Chernobyl input) 


\section{Abstract}

Radioactive fallout due to the Fukushima reactor explosion in Japan was detected in environmental samples collected in France. The presence of ${ }^{131} \mathrm{I}$ in aerosols $\left(200 \pm 6 \mu \mathrm{Bq} \mathrm{m} \mathrm{m}^{-3}\right)$ collected at the Pic du Midi observatory, located at $2877 \mathrm{~m}$ altitude in the French Pyrénées, indicated that the Japanese radioactive cloud reached France between 22 and 29 March, i.e. less than two weeks after the initial emissions, as suggested by a ${ }^{137} \mathrm{Cs} /{ }^{134} \mathrm{Cs}$ ratio of 1.4 . Cesium radioisotopes $\left({ }^{134} \mathrm{Cs}\right.$ and $\left.{ }^{137} \mathrm{Cs}\right)$ were not detected in this sample but they were present in the aerosol sample collected the next week, i.e. between 29 March and 05 April (about 10 $\left.\mu \mathrm{Bq} \mathrm{m}{ }^{-3}\right)$. We also report ${ }^{131} \mathrm{I}$ activities measured in grass $\left(1.1-11 \mathrm{~Bq} \mathrm{~kg}^{-1}\right.$; fresh weight $)$ and soil samples $\left(0.4 \mathrm{~Bq} \mathrm{~kg}^{-1}\right)$ collected in the Seine River basin between 30 March and 10 April. The ${ }^{134} \mathrm{Cs}$ from the damaged Fukushima power plant was also detected in grass collected in the Seine River basin between 31 March and 10 April $\left(0.2-1.6 \mathrm{~Bq} \mathrm{~kg}^{-1}\right.$ fresh weight, with a ${ }^{137} \mathrm{Cs} /{ }^{134} \mathrm{Cs}$ ratio close to 1 , which is consistent with Fukushima radioactive release). Despite the installation of a network of nested stations to collect suspended matter in the upstream part of the Seine River basin, ${ }^{131}$ I was only detected in suspended matter $\left(4.5-60 \mathrm{~Bq} \mathrm{~kg}^{-1}\right)$ collected at the most upstream stations between 30 March and 12 April. Neither ${ }^{131} \mathrm{I}$ nor ${ }^{134} \mathrm{Cs}$ have been detected in environmental samples since the end of April 2011, because of the rapid decay of ${ }^{131}$ I and the very low activities of ${ }^{134} \mathrm{Cs}$ (about 400 times lower than after Chernobyl accident). 


\section{Introduction}

Tohoku earthquake that occurred on 11 March 2011 was exceptionally powerful (moment magnitude Mw of 9.0; Simons et al., 2011). It triggered a violent tsunami with an exceptional wave, which height reached up to $20 \mathrm{~m}$ or even $40 \mathrm{~m}$ locally. The coincidence between this earthquake and the tsunami led to the destruction of more than $600 \mathrm{~km}$ of Japanese coastline, to numerous deaths and injuries (about 20,000 people were killed or are still missing), and to the immersion of the land up to $10 \mathrm{~km}$ inland (Imamura, 2011). Reactors of the affected nuclear power plants were automatically stopped, but the loss of cooling systems was observed at three reactors of Fukushima-Daiichi power plant. People were evacuated within a $20-\mathrm{km}$ radius around the power plant because of the possible occurrence of an explosion and radioactive fallout (Irikura, 2011). Several explosions occurred during the next few days (i.e., 12-15 March). The Nuclear and Industrial Safety Agency of Japan (NISA) attributed a 7-level to this accident according to INES - International Nuclear and Radiological Event Scale (IAEA, 2011). A similar 7-level was also attributed to the Chernobyl accident that occurred on 26 April 1986 in Ukraine. A cloud loaded with radioactive elements was emitted from the damaged reactors, blown out eastward of Japan to the Pacific Ocean and then detected in parts of the Northern hemisphere.

The U.S. Environmental Protection Agency reported the presence of 18 fission product radionuclides (e.g., $\left.{ }^{137} \mathrm{Cs},{ }^{131} \mathrm{I}\right)$ in air filter samples collected on 22 March 2011 (EPA, 2011). The radioactive cloud then moved over the USA, the Atlantic Ocean and then diffused across Europe. Airborne radionuclides are continuously monitored by a European network of measurement stations (150 locations). Based on this monitoring, Masson et al. (2011) provided maps describing the transport and dispersion in the air of Fukushima radionuclides over Europe.

Additional radionuclide fallout was reported from melted snow and rainwater samples collected across the European continent (e.g., from Greece, Manolopoulou et al., 2011; from Central Russia, Bolsunovsky and Dementyev, 2011). In contrast and to our knowledge, there are only few studies reporting fallout radionuclide activity measurements in soil, river sediment and grass samples collected in Europe after the Fukushima accident. Pittauerova et al. (2011) reported ${ }^{131} \mathrm{I},{ }^{134} \mathrm{Cs}$ and ${ }^{137} \mathrm{Cs}$ activities determined in a total of twelve rainwater, 
river sediment, soil, grass and cow milk samples collected in Northwest Germany. Beresford et al. (in press) provided measurements of ${ }^{131} \mathrm{I}$ originating from Fukushima in grass samples collected across Great Britain. In France, one study investigated the transfer of ${ }^{131}$ I from Fukushima to vegetation and milk, but it only focused on study sites located in southern France (Parache et al., 2011).

This paper compiles and provides additional radionuclide data. The aim of the present study was to determine whether we could find in France any evidence of radioactive fallout associated with the Fukushima accident. Therefore, we analyzed environmental samples collected in France, such as grass, soil and suspended sediment of the Seine River basin to check whether radioisotopes from Fukushima could be detected. To complement this study conducted at low altitude, we also investigated aerosol samples collected at high altitude (2877) in the French Pyrénées. Very few samples were analyzed at such an altitude in Europe.

\section{Materials and methods}

\subsection{Collection of aerosols at the Pic du Midi mountain (southern France)}

\subsubsection{Sampling}

Aerosols were collected using a pumping system linked up to the Whole Air Inlet (WAI) at the Pic du Midi observatory located at $2877 \mathrm{~m}$ above sea level in the French Pyrénées; Fig. 1a) in the framework of the ORAURE network (Observations en Réseaux des Aérosols à Usage de Recherches Environnementales). A volume of $400 \mathrm{~m}^{3}$ of air was filtered using Teflon filters (Pall Zefluor, $47 \mathrm{~mm}$ diameter, $2.0 \mu \mathrm{m}$ porosity) during one-week periods. The air flow rate in the WAI system was fixed to capture all aerosols with a diameter lower than $30 \mu \mathrm{m}$. We followed strict quality-controlled procedures to avoid any contamination of the samples.

\subsubsection{Gamma spectrometry measurements}

Radioisotope activities (i.e., ${ }^{131} \mathrm{I},{ }^{137} \mathrm{Cs}$ and ${ }^{134} \mathrm{Cs}$ as well as ${ }^{7} \mathrm{Be}$ ) on the filters were determined using low-background gamma-ray spectrometry at the LAFARA underground laboratory located in Ferrières, French Pyrénées (van Beek et al., 2010; van Beek et al., submitted). Two germanium detectors are protected from cosmic radiations under $85 \mathrm{~m}$ of rock ( $215 \mathrm{~m}$ water equivalent). A very low background ( $<5$ counts per minute) is thus achieved in this laboratory, allowing the detection of low-gamma activities in environmental 
samples (van Beek et al., submitted). The filters were analyzed using a high-purity germanium coaxial detector (GEM-FX series) provided by ORTEC/AMETEK (van Beek et al., in press). The germanium crystal has a diameter of $85 \mathrm{~mm}$ and a length of $32.2 \mathrm{~mm}$, which is equivalent to a volume of $183 \mathrm{~cm}^{3}$ of germanium. The spectrum of the detector covers a wide range of energies, ranging from 10 to $2700 \mathrm{keV}$. The detector resolution (FWHM: full width at half maximum) determined at $122 \mathrm{keV}$ and $1.33 \mathrm{MeV}$ are $0.669 \mathrm{keV}$ and $1.65 \mathrm{keV}$, respectively. The detector is protected by a lead castle: $2 \mathrm{~cm}$ of low-activity lead $\left(<10 \mathrm{~Bq} \mathrm{~kg}^{-}\right.$ ${ }^{1}$ ) and additionally $13 \mathrm{~cm}$ regular lead $\left(<50 \mathrm{~Bq} \mathrm{~kg}^{-1}\right)$. Finally, $4 \mathrm{~cm}$ of pure copper cover the interior of the lead castle.

We used RGU-1 and IAEA Standard \#175 powder standards provided by IAEA (International Atomic Energy Agency) that we placed onto a $47 \mathrm{~mm}$ filter to determine the detection efficiencies for the radionuclides reported in this study. RGU-1 is a certified reference material prepared using $U$ ore diluted with floated silica powder - with all the daughters of the series being in secular equilibrium. IAEA Standard \#175 allows us to determine the detection efficiencies for ${ }^{137} \mathrm{Cs}$ and ${ }^{40} \mathrm{~K}$. The detection efficiencies for ${ }^{131} \mathrm{I},{ }^{134} \mathrm{Cs}$ and ${ }^{7} \mathrm{Be}$ were then interpolated at the corresponding energies, 365, 604 and $478 \mathrm{keV}$, respectively. For the shortlived ${ }^{131} \mathrm{I}$ and ${ }^{7} \mathrm{Be}$, decay correction was applied according to the middle of the sampling period (one week interval).

\section{France)}

\subsection{Collection of soil, sediment and grass samples in the Seine River basin (northern}

\subsubsection{Sampling}

Soil, suspended sediment and grass samples were collected within the upstream part of the Seine River basin (Fig. 1a). The location of sampling points is shown in Fig. 1b. We collected soil samples in cropland fields that are potential sediment source areas. Five subsamples of surface material (top $2 \mathrm{~cm}$ ) were collected and well-mixed to provide a homogeneous sample. Additionnally, suspended sediment samples were collected in upstream Orgeval and Saulx Rivers (i.e., upstream tributaries of the Seine River) at four different nested 
stations (i.e., Mélarchez, Grange Allard, Ribeaucourt, Vitry-le-François) between 16 March and 14 June 2011.We used metallic cylindric traps submerged into the water by using a rope attached to a nearby tree trunk on the river bank. Finally, twelve fresh grass samples were collected from uncut parklands or gardens in both Orgeval and Saulx subcatchments as well as in the vicinity of our laboratory (i.e. LSCE) between 30 March and 14 June 2011.

\subsubsection{Gamma spectrometry measurements}

Fresh grass samples were weighed and placed into 1-L Marinelli plastic containers.

They were analysed as soon as possible after sampling. All results were decay corrected to the day of sampling. Soil and suspended sediment samples were sieved to $2 \mathrm{~mm}$, dried and packed into 15 or $60-\mathrm{ml}$ (depending on the quantity available) pre-tared polyethylene specimen cups and sealed airtight to contain ${ }^{222} \mathrm{Rn}$ and allow ingrowth of its decay products. The ${ }^{131} \mathrm{I}(364.5 \mathrm{keV}),{ }^{7} \mathrm{Be}(477.6 \mathrm{keV}),{ }^{137} \mathrm{Cs}(661.6 \mathrm{keV})$, and ${ }^{210} \mathrm{~Pb}(46.5 \mathrm{keV})$ activities in this material were determined by gamma spectrometry using the seven very low-background coaxial N- and P-types GeHP detectors (Canberra / Ortec) available at the LSCE. For soil and suspended sediment samples, "excess" ${ }^{210} \mathrm{~Pb}$ was calculated by subtracting the supported activity (determined using two ${ }^{238} \mathrm{U}$ daughters, i.e. ${ }^{214} \mathrm{~Pb}$, by taking the average count number at 295.2 and $351.9 \mathrm{keV}$, and ${ }^{214} \mathrm{Bi}$ at $609.3 \mathrm{keV}$ ) from the total activity of ${ }^{210} \mathrm{~Pb}$ (measured at $46.5 \mathrm{keV}$; Le Cloarec et al., 2011).

When the available material was insufficient $(<5 \mathrm{~g})$, suspended sediment samples were placed in polypropylene tubes, sealed airtight, and counted on a well-type Ge detector. Counting time of soil and suspended sediment samples varied between $8 \times 10^{4}$ and $3 \times 10^{5} \mathrm{~s}$. All measured counts were corrected for background levels measured at least every 2 months as well as for detector and geometry efficiencies. Results were systematically expressed in Bq $\mathrm{kg}^{-1}$. Counting efficiencies and quality insurance were conducted using internal and certified 
IAEA standards (e.g., IAEA-135, IAEA-375, IAEA-CU-2006-03, IAEA-Soil-6, RGU-1, RGTh-1) prepared in the same specimen cups as the samples. Efficiencies were interpolated for ${ }^{7} \mathrm{Be}$ energy.

Furthermore, to provide an indication on the "age" of suspended sediment collected in the river traps, we calculated the ${ }^{7} \mathrm{Be} /{ }^{210} \mathrm{~Pb}_{\mathrm{xs}}$ ratio, as proposed by Matisoff et al. (2005). A decrease in the ${ }^{7} \mathrm{Be} /{ }^{210} \mathrm{~Pb}_{\mathrm{xs}}$ ratio can then alternatively be explained by (i) an increase in the sediment residence time (given that ${ }^{7} \mathrm{Be}$ decay is faster than ${ }^{210} \mathrm{~Pb}$ xs decay) or by (ii) the dilution of sediment enriched in ${ }^{7} \mathrm{Be}$ by sediment poorer in ${ }^{7} \mathrm{Be}$. Consequently, calculation of this ratio could indicate whether aging and/or dilution of sediment occurred in the river (Evrard et al., 2010).

\section{Results and discussion}

\subsection{Aerosols collected on top of Pic du Midi (2877 m, southern France)}

Radionuclide activities reported in this study are integrated over one-week intervals (Table 1). Data reported for the air filter samples collected at the Pic du Midi observatory constitute, to our knowledge, the data obtained at the highest altitude in France. These data provide thus a good complement to the measurements obtained in lowlands and at lower altitudes by the French Institute of Radioprotection and Nuclear Safety (IRSN, 2011). Only two samples (\#123 and \#124) were analyzed sufficiently quickly after the date of collection to allow detection of ${ }^{131} \mathrm{I}$ (half life of 8.02 days). All other samples were analyzed several weeks after sampling, which prevented the detection of potential ${ }^{131}$ I activities on the filters. Only ${ }^{137} \mathrm{Cs},{ }^{134} \mathrm{Cs}$ and ${ }^{7} \mathrm{Be}$ activities could be determined for these samples. We measured a ${ }^{131} \mathrm{I}$ activity of $200 \pm 6 \mu \mathrm{Bq} \mathrm{m} \mathrm{m}^{-3}$ on the filter that collected aerosols between 22 March and 29 March 2011. This activity indicates the presence of the radioactive cloud above France during 
this period, because ${ }^{131} \mathrm{I}$ activities measured in France are typically $<0.03 \mu \mathrm{Bq} \mathrm{m}^{-3}$ (Loaiza et al., submitted). However, our sample integrates a one-week interval and we cannot determine the exact day during which the radioactive cloud reached France. The ${ }^{131}$ I activity reported here shows a good agreement with the activity determined on filters collected in the French Alps (Loaiza et al., submitted). These authors collected several filters during the same time interval (25-29 March) and the resulting mean ${ }^{131} \mathrm{I}$ activity varied between $248 \pm 2 \mu \mathrm{Bq} \mathrm{m}{ }^{-3}$ (25-27 March) and $144 \pm 5 \mu \mathrm{Bq} \mathrm{m}{ }^{-3}$ (29 March). Higher ${ }^{131} \mathrm{I}$ activities were reported later, amounting up to $522 \mu \mathrm{Bq} \mathrm{m}{ }^{-3}$ (02-03 April; Loaiza et al., submitted). These data can also be compared to another altitude station, Jungfraujoch station (Switzerland, $3450 \mathrm{~m}$ ) where ${ }^{131} \mathrm{I}$ activity levels were found to reach up to $900 \mu \mathrm{Bq} \mathrm{m} \mathrm{m}^{3}$ (Masson et al., 2011).

${ }^{134} \mathrm{Cs}$ and ${ }^{137} \mathrm{Cs}$ were not detected in this aerosol sample collected at the end of March (when ${ }^{131}$ I was detected) but they were present in the aerosol sample collected the following week, i.e. between 29 March and 05 April (sample \#125). We report ${ }^{137} \mathrm{Cs}$ and ${ }^{134} \mathrm{Cs}$ activities of $10 \pm 2$ and $7 \pm 2 \mu \mathrm{Bq} \mathrm{m}^{-3}$, respectively. These activities are in the same order of magnitude as ${ }^{137} \mathrm{Cs}$ (mean of $17.5 \mu \mathrm{Bq} \mathrm{m}{ }^{-3}$ ) and ${ }^{134} \mathrm{Cs}$ (mean of $19.5 \mu \mathrm{Bq} \mathrm{m} \mathrm{m}^{-3}$ ) activities determined on filters collected in the French Alps during the same period (Loaiza et al., submitted). Only one sample (\#125) allows us to provide a value of 1.4 for the ${ }^{137} \mathrm{Cs} /{ }^{134} \mathrm{Cs}$ ratio in aerosols. As a comparison, the ${ }^{137} \mathrm{Cs} /{ }^{134} \mathrm{Cs}$ ratio in the Fukushima fallout was found to be close to 1.0 , whereas it was in the range of 0.5-0.6 in the Chernobyl fallout in 1986 (Masson et al., 2011). The ${ }^{137} \mathrm{Cs} /{ }^{134} \mathrm{Cs}$ ratio itself is not conclusive enough in order to determine the origin of the radioactive contamination. However, the presence of a significant ${ }^{134} \mathrm{Cs}$ activity suggests a recent input into the atmosphere, and it is very probably associated with Fukushima radioactive release. Finally, we also report ${ }^{7} \mathrm{Be}$ activities on the filters $\left({ }^{7} \mathrm{Be}\right.$ being a natural cosmogenic radioisotope which was not associated with the radioactive cloud). The ${ }^{7} \mathrm{Be}$ 
activities that we determined also remained in the same order of magnitude as the activities reported during the same time interval by Loaiza et al. (submitted), thereby confirming the relevance of our values.

\subsection{Samples collected in the Seine River basin (Northern France)}

Overall, the spring of 2011 was exceptionally dry in France. Extremely low rainfall (total amount $<5 \mathrm{~mm}$ ) was recorded in Paris at the end of March and early in April. Then, the weather remained almost completely dry until early June (Fig. 2). Masson et al. (2011) showed that airborne concentrations of ${ }^{131}$ I have increased in western Europe until 28-30 March. Then, a second peak of similar magnitude was observed between 3-5 April. Both fallout periods coincided with periods of low rainfall $(\leq 5 \mathrm{~mm})$ in the Paris region (Fig. 2).

\subsubsection{Grass samples}

Presence of radioiodine $\left({ }^{131} \mathrm{I}\right)$ was detected in grass between 30 March and 10 April. The highest ${ }^{131}$ I activity $\left(11 \pm 1 \mathrm{~Bq} \mathrm{~kg}^{-1}\right.$; fresh weight $\left.-\mathrm{FW}\right)$ was found in the sample collected in Palaiseau on 5 April. This observation is consistent with the measurements conducted in Great Britain, where Beresford et al. (in press) reported peaks of ${ }^{131}$ I activities in grass samples collected between 4-6 April 2011. Radioiodine activities measured in grass samples from the Parisian Basin remained in the activity range reported by IRSN for samples collected across France (i.e., 0.5-15 $\mathrm{Bq} \mathrm{kg}^{-1} \mathrm{FW}$; IRSN, 2011), but they were generally higher than the activities measured on grass collected in southern France $\left(0.1-4 \mathrm{~Bq} \mathrm{~kg}^{-1} \mathrm{FW}\right.$, with the exception of one grass sample collected in Agen showing an activity of $9 \mathrm{~Bq} \mathrm{~kg}^{-1} \mathrm{FW}$;

Parache et al., 2011). 

detected in the grass samples collected between 31 March and 10 April. This result is consistent with the observation that ${ }^{134} \mathrm{Cs}$ and ${ }^{137} \mathrm{Cs}$ were detected later than ${ }^{131} \mathrm{I}$, because they exceeded the detection criterion later than radioiodine (Masson et al., 2011). The activities measured in the Seine River basin remained in the same order of magnitude but they were slightly higher than those reported for three grass samples collected in Northwestern Germany (0.1-0.3 Bq kg-1 FW of ${ }^{134} \mathrm{Cs}$ and $0.2-1.6 \mathrm{~Bq} \mathrm{~kg}^{-1} \mathrm{FW}$ of ${ }^{137} \mathrm{Cs}$; Pittauerová et al., 2011). Values of the ${ }^{131} \mathrm{I} /{ }^{137} \mathrm{Cs}$ ratio varied within a range of $1.7 \pm 0.4-9.0 \pm 3.8$, and were maximal between 31 March and 5 April. These values are similar to the ones observed in Northwestern Germany during the same period (Pittauerová et al., 2011). Similar values were obtained for ${ }^{131} \mathrm{I} /{ }^{134} \mathrm{Cs}$ ratio. The ${ }^{137} \mathrm{Cs} /{ }^{134} \mathrm{Cs}$ ratio varied indeed between $0.7 \pm 0.4$ and $5.0 \pm 3.0$. Masson et al. (2011) showed that values of this ratio in the Fukushima fallout were close to 1, whereas it was in the range $0.5-0.6$ in the Chernobyl fallout in 1986. Furthermore, it must be noted that both ${ }^{134} \mathrm{Cs}$ and ${ }^{137} \mathrm{Cs}$ from previous sources (i.e., global fallout from nuclear weapon tests; Chernobyl fallout) are normally not detected anymore in grass samples in this region, as indicated by the activities below detection limits obtained before $31 \mathrm{March}$ and after 10 April (Table 2). These observations therefore indicate that ${ }^{134} \mathrm{Cs}$ and ${ }^{137} \mathrm{Cs}$ detected in grass of the Parisian Basin were very likely released by the Fukushima accident.

Fresh grass density in the field (about $1.2 \mathrm{~kg} \mathrm{~m}^{-2}$ ) was calculated in the vicinity of LSCE laboratory in order to determine the inventory of ${ }^{134} \mathrm{Cs}$ in the soils. This inventory remained very low (about $2 \mathrm{~Bq} \mathrm{~m}^{-2}$ ) by 10 April 2011. This inventory is about three orders of magnitude smaller than the ${ }^{137} \mathrm{Cs}$ inventories in soils of the region (about $1500-2000 \mathrm{~Bq} \mathrm{~m}^{-2}$ by 2011; recalculated after Sogon et al., 1999). This estimation is consistent with the estimations made for German samples by Pittauerová et al. (2011). 
A low ${ }^{131}$ I activity was detected in soils on 30 March $\left(0.4 \pm 0.1 \mathrm{~Bq} \mathrm{~kg}^{-1}\right.$; Table 3$)$. Presence of ${ }^{131}$ I was only detected in two suspended sediment samples collected in small tributaries of the Seine River basin (between $4.5 \pm 1.7$ and $60 \pm 30 \mathrm{~Bq} \mathrm{~kg}^{-1}$ ) between $30 \mathrm{March}^{\circ}$ and 12 April (Table 3). Radioiodine was exclusively detected in upstream river reaches, where sediment can be directly supplied by runoff from agricultural fields. The fine fraction of sediment probably concentrated ${ }^{131} \mathrm{I}$ (having a partition coefficient or $\mathrm{K}_{\mathrm{D}}$ of $10^{4} \mathrm{~L} \mathrm{~kg}^{-1}$; Fischer et al., 2009), explaining why activities could reach up to $60 \pm 30 \mathrm{~Bq} \mathrm{~kg}^{-1}$ at Grange Allard station. However, the ${ }^{131}$ I activity level remained very low in potential sediment sources and a dilution effect probably led to the decrease of ${ }^{131}$ I activities when sediment was transferred downstream. Because of its rapid decay and the low level of activities measured upstream, we were not able to detect this radioisotope at downstream river stations (i.e., $<50$ $\mathrm{Bq} \mathrm{kg}^{-1}$ at Ribeaucourt and Vitry-le-François stations). Values of the ${ }^{7} \mathrm{Be} /{ }^{210} \mathrm{~Pb}_{\mathrm{xs}}$ ratio indicate that these results remained valid whatever the "age" of sediment, i.e. before and after the delivery of fresh sediment to the river as reflected by the increase in this ratio after rainfall (e.g., on 12 April and on 7 June at Grange Allard station).

The presence of ${ }^{134} \mathrm{Cs}$ could never be detected in suspended sediment throughout the study period. This result was confirmed by additional analyses conducted on the very low background detectors available at the Laboratoire Souterrain de Modane (Reyss et al., 1995). In contrast, ${ }^{137} \mathrm{Cs}$ from previous sources (i.e., global fallout from nuclear weapon tests; Chernobyl fallout) is continuously detected in soils and suspended sediment in this area (1.2$8 \mathrm{~Bq} \mathrm{~kg}^{-1}$; Table 2). This is reflected by the low values obtained for the ${ }^{131} \mathrm{I} /{ }^{137} \mathrm{Cs}$, showing that the contribution of "old" ${ }^{137} \mathrm{Cs}$ is dominant.

\section{Conclusions}


It was possible to detect radionuclides emitted by the Fukushima power plant accident in environmental samples collected in France. Radioactivity measurements conducted on aerosols collected using air filters at the Pic $d u$ Midi observatory showed that the radioactive cloud reached France between 22 - 29 March 2011 as deduced by the presence of a ${ }^{131}$ I activity of about $200 \pm 6 \mu \mathrm{Bq} \mathrm{m}{ }^{-3}$ on the filter collected during this period. These air filter samples provide, to our knowledge, the data obtained at the highest altitude in France and thus complement those measured at lower altitudes and reported by other studies. The presence of ${ }^{134} \mathrm{Cs}$ was also detected in air filters between 29 March and 4 April. Calculation of a

${ }^{137} \mathrm{Cs} /{ }^{134} \mathrm{Cs}$ ratio close to $1 \mathrm{in}$ this sample suggested that it was associated with Fukushima radioactive release. The ${ }^{134} \mathrm{Cs},{ }^{137} \mathrm{Cs}$ and ${ }^{131} \mathrm{I}$ activities reported in aerosols remained in the same order of magnitude as the activities determined in aerosols in the French Alps over the same period. The ${ }^{131}$ I activities were detected in grass, soil and river suspended sediment samples collected between 30 March - 12 April in the Seine River Basin. In contrast, ${ }^{134} \mathrm{Cs}$ activities were only reported in grass samples between 31 March - 10 April. Low values of the ${ }^{137} \mathrm{Cs} /{ }^{131}$ I ratio calculated in suspended matter outlined the contribution of "old" ${ }^{137} \mathrm{Cs}$ from the global nuclear weapon tests and Chernobyl fallout in suspended sediment conveyed by the rivers in the Seine River basin. A total ${ }^{134} \mathrm{Cs}$ input of $2 \mathrm{~Bq} \mathrm{~m}^{-2}$ was measured in grass of the Parisian Basin by 10 April 2011. Overall, this fallout radionuclide input is very low. It is 400 times lower than the Chernobyl accident input in 1986 (i.e., $800 \mathrm{~Bq} \mathrm{~m}^{-2}$ in the Paris region). ${ }^{131}$ I and ${ }^{134} \mathrm{Cs}$ have not been detected in environmental samples anymore since the end of April 2011, because of the rapid decay and dilution of ${ }^{131} \mathrm{I}$ and the very low ${ }^{134} \mathrm{Cs}$ activities measured in France.

\section{Acknowledgements}

We are grateful to Marc Souhaut for his technical help assistance at the LAFARA underground laboratory. We also greatly acknowledge the technical team at the Observatory 
for its help to conduct sample collection, as well as Eline Sallé and Dominique Blamart for assisting us to collect grass in the Parisian Basin.

\section{References}

Beresford, N.A., Barnett, C.L., Howard, B.J., Howard, D.C., Wells, C., Tyler, A.N., Bradley, S., Copplestone, D., in press. Observations of Fukushima fallout in Great Britain. Journal of Environmental Radioactivity.

Bolsunovsky, A., Dementyev, D., 2011. Evidence of the radioactive fallout in the center of Asia (Russia) following the Fukushima Nuclear Accident. Journal of Environmental Radioactivity 102(11), 1062-1064.

Bossew, P., Kirchner, G., De Cort, M., de Vries, G., Nishev, A., de Felice, L., in press. Radioactivity from Fukushima Dai-ichi in air over Europe; Part 1: Spatio-temporal analysis. Journal of Environmental Radioactivity.

EPA, 2011. United States Environmental Protection Agency. Japanese Nuclear Emergency: EPA's radiation monitoring. http://www.epa.gov/japan2011/ (Latest access on 06/01/12).

Evrard, O., Némery, J., Gratiot, N., Duvert, C., Ayrault, S., Lefèvre, I., Poulenard, J., Prat, C., Bonté, P., Esteves, M., 2010. Sediment dynamics during the rainy season in tropical highland catchments of central Mexico using fallout radionuclides. Geomorphology 124, 42-54.

Fischer, H.W., Ulbrich, S., Pittauerová, D., Hettwig, B., 2009. Medical radioisotopes in the environment - following the pathway from patient to river sediment. Journal of Environmental Radioactivity 100, 1079-1085.

Manolopoulou, M., Vagena, E., Stoulos, A., Ioannidou, A., Papastefanou, C., 2011. Radioiodine and radiocesium in Thessaloniki, Northern Greece due to the Fukushima nuclear accident. Journal of Environmental Radioactivity 102, 796-797.

Masson, O., Baeza, A., Bieringer, J., Brudecki, K., Bucci, S., Cappai, M., Carvalho, F.P., Connan, O., Cosma, C., Dalheimer, A., Didier, D., Depuydt, G., De Geer, L.E., De Vismes, A., Gini, L., Groppi, F., Gudnason, K., Gurriaran, R., Hainz, D., Halldórsson, Ó, Hammond, D., Hanley, O., Holeý, K., Homoki, Zs., Ioannidou, A., Isajenko, K., Jankovic, M., Katzlberger, C., Kettunen, M., Kierepko, R., Kontro, R., Kwakman, P.J.M., Lecomte, M., Leon Vintro, L., Leppänen, A.-P., Lind, B., Lujaniene, G., McGinnity, P., McMahon, C., Malá, H., Manenti, S., Manolopoulou, M., Mattila, A., Mauring, A., Mietelski, J.W., Møller, B., Nielsen, S.P., Nikolic, J., Overwater, R.M.W., Pálsson, S.E., Papastefanou, C., Penev, I., Pham, M.K., Povinec, P.P., Ramebäck, H., Reis, M.C., Ringer, W., Rodriguez, A., Rulík, P., Saey, P.R.J., Samsonov, V., Schlosser, C., Sgorbati, G., Silobritiene, B.V., Söderström, C., 
Sogni, R., Solier, L., Sonck, M., Steinhauser, G., Steinkopff, T., Steinmann, P., Stoulos, S., Sýkora, I., Todorovic, D., Tooloutalaie, N., Tositti, L., Tschiersch, J., Ugron, A., Vagena, E., Vargas, A., Wershofen, H., Zhukova, O., 2011. Tracking of airborne radionuclides from the damaged Fukushima Dai-Ichi nuclear reactors by European networks. Environmental Science and Technology 45, 7670-7677.

Parache, V., Pourcelot, L., Roussel-Debet, S., Orjollet, D., Leblanc, F., Soria, C., Gurriaran, R., Renaud, Ph., Masson, O., 2011. Transfer of ${ }^{131}$ I from Fukushima to vegetation and milk in France. Environmental Science and Technology 45, 9998-10003.

Pittauerová, D., Hettwig, B., Fischer, H.W., 2011. Fukushima fallout in Northwest German environmental media. Journal of Environmental Radioactivity 102, 877-880.

Imamura, F., 2011. Tsunami disaster and impact due to the 2011 Tohoku earthquake. Session on "Grand Challenges in Natural Hazard". IUGG $25^{\text {th }}$ General Assembly, Melbourne (Australia), 2 July 2011.

Irikura, K., 2011. Accidents at Fukushima No.1 nuclear power plant caused by the 2011 Tohoku earthquake. Session on "Grand Challenges in Natural Hazard". IUGG $25^{\text {th }}$ General Assembly, Melbourne (Australia), 2 July 2011.

IRSN, 2011. Synthèse des résultats des mesures de radioactivité dans le cadre de la surveillance de l'impact à très longue distance des rejets de l'accident de Fukushima Dai-ichi en France. Note d'information $n^{\circ} 15$. Version du 8 juin 2011, mise à jour le 10 juin 2011. http://www.irsn.fr/FR/Actualites_presse/Actualites/Pages/201103 situation_en_france.aspx (Latest access on 06/01/12).

Le Cloarec, M.F., Bonté, P.H., Lestel, L., Lefèvre, I., Ayrault, S., 2011. Sedimentary record of metal contamination in the Seine River during the last century. Physics and Chemistry of the Earth, Parts A/B/C 36(12), 515-529.

Loaiza, P., Brudanin, V., Piquemal, F., Reyss, J-L., Stekl, I., Warot, G., Zampaolo, M., in review. Air radioactivity levels following the Fukushima reactor accident measured at the Laboratoire Souterrain de Modane, France. Submitted to Journal of Environmental Radioactivity.

Matisoff, G., Wilson, C.G., Whiting, P.J., 2005. The ${ }^{7} \mathrm{Be} /{ }^{210} \mathrm{~Pb}_{\mathrm{xs}}$ ratio as an indicator of suspended sediment age or fraction new sediment in suspension. Earth Surface Processes \& Landforms, 30, 1191-1201.

Simons et al., 2011. The 2011 Magnitude 9.0 Tohoku-Oki Earthquake: Mosaicking the Megathrust from Seconds to Centuries. Science 332 (6036): 1421-1425.

Sogon, S.,Penven, M-J ., Bonté, P., 1999. Estimation of sediment yield and soil loss using suspended sediment load and ${ }^{137} \mathrm{Cs}$ measurements on agricultural land, Brie Plateau, France. Hydrobiologia 410, 251-261. 
377 van Beek, P., Souhaut, M., Reyss, J-L., 2010. Measuring the radium quartet $\left({ }^{226} \mathrm{Ra},{ }^{228} \mathrm{Ra}\right.$,

$378{ }^{224} \mathrm{Ra},{ }^{223} \mathrm{Ra}$ ) in water samples using gamma spectrometry. Journal of Environmental

379 Radioactivity 101, 521-529.

380 van Beek, P., Souhaut, M., Lansard, B., Bourquin, M., Reyss, J-L., Jean, P., von Ballmoos, P., 381 in press. LAFARA: a new underground laboratory in the French Pyrenees for ultra low-level

382 gamma-ray spectrometry. Submitted to Journal of Environmental Radioactivity.

383

\section{$384 \quad$ Figure captions}

385 Figure 1. (a) Location of the Seine River basin and the Pic du Midi observatory in France; (b)

386 detailed map of the main Seine River tributaries and the grass, soil and suspended sediment

387 sampling sites.

388 Figure 2. Rainfall recorded at Paris during the study period. 
Figure 1

Fig. 1

(a)
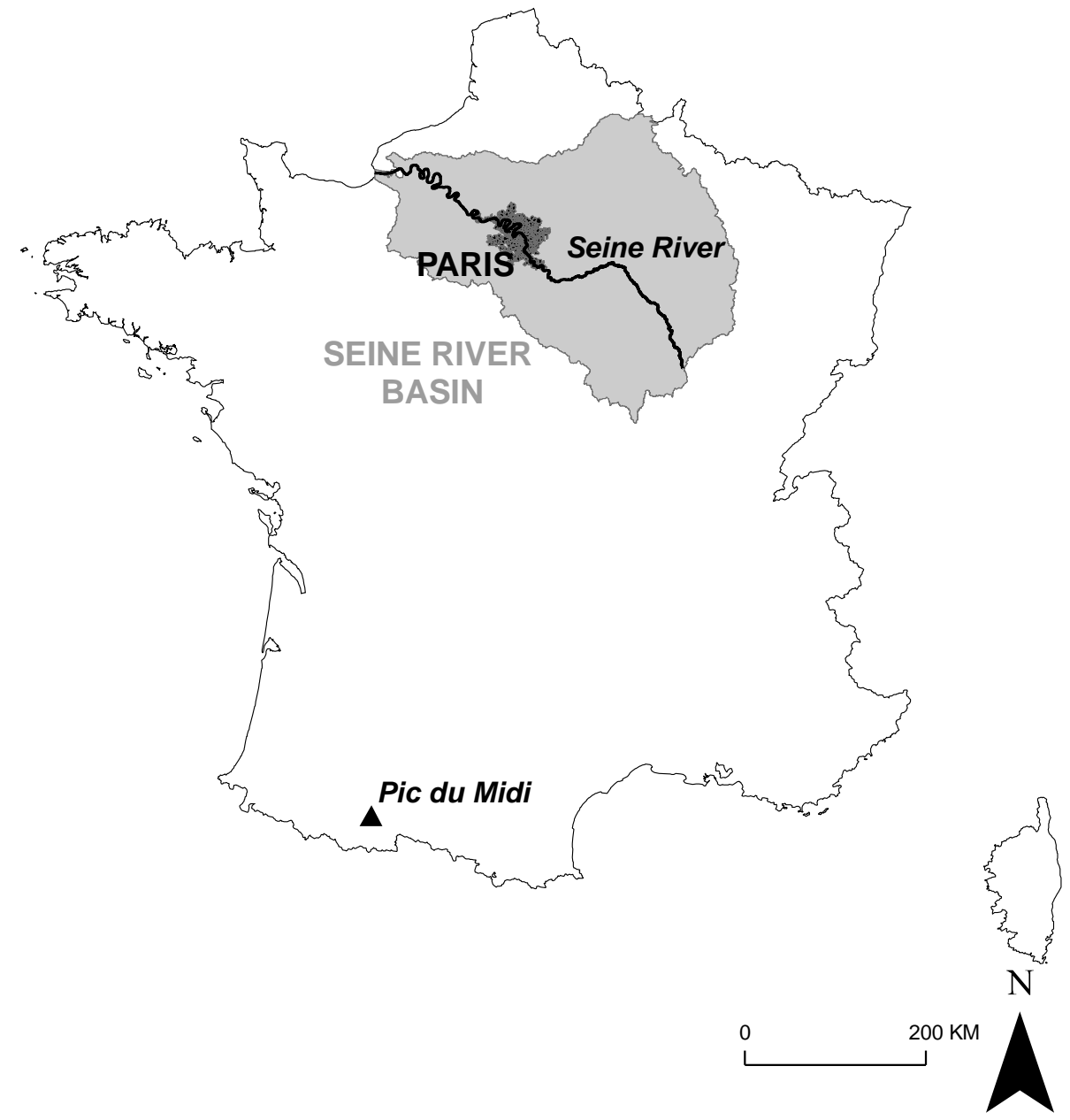
(b)

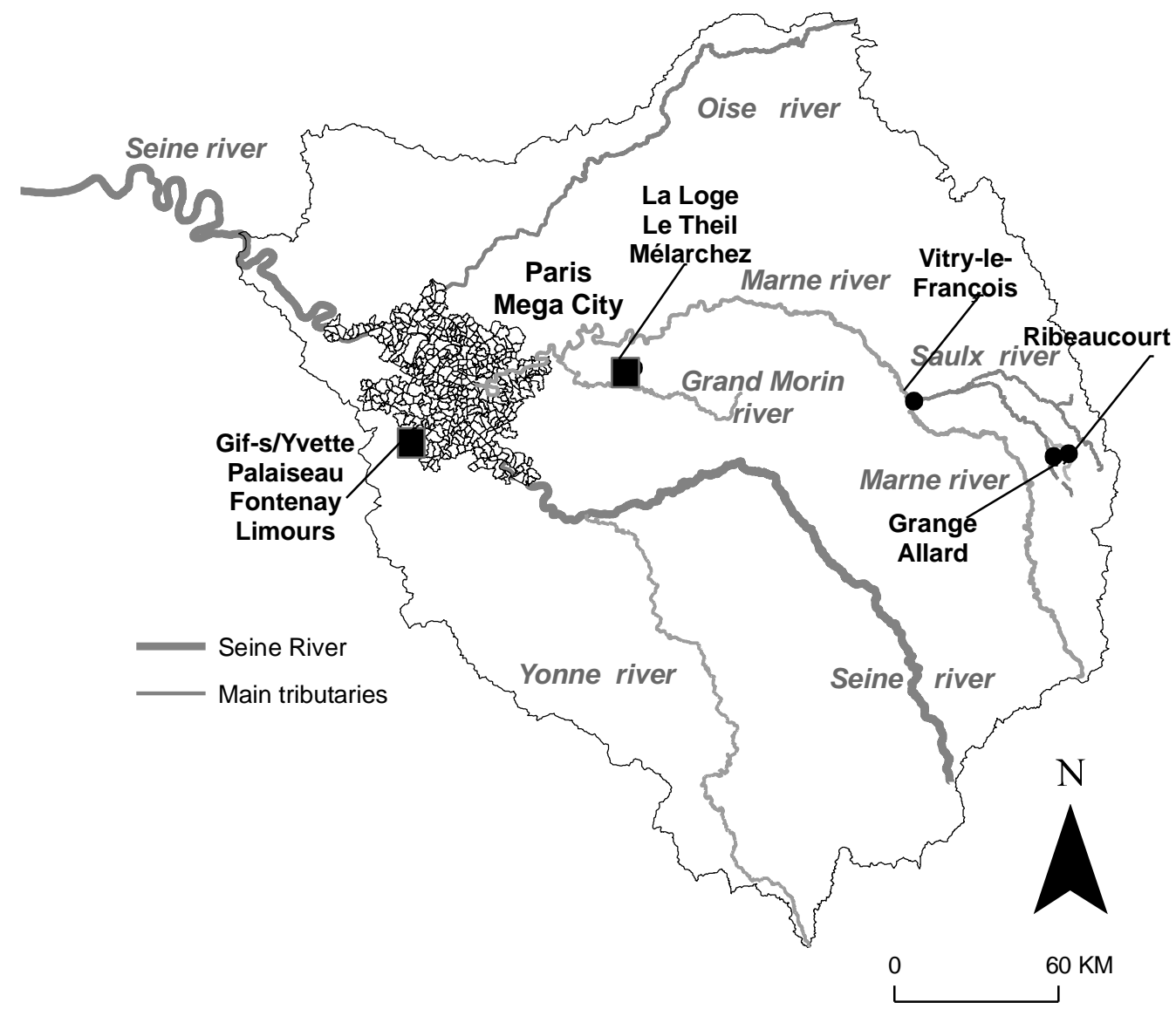


Figure 2

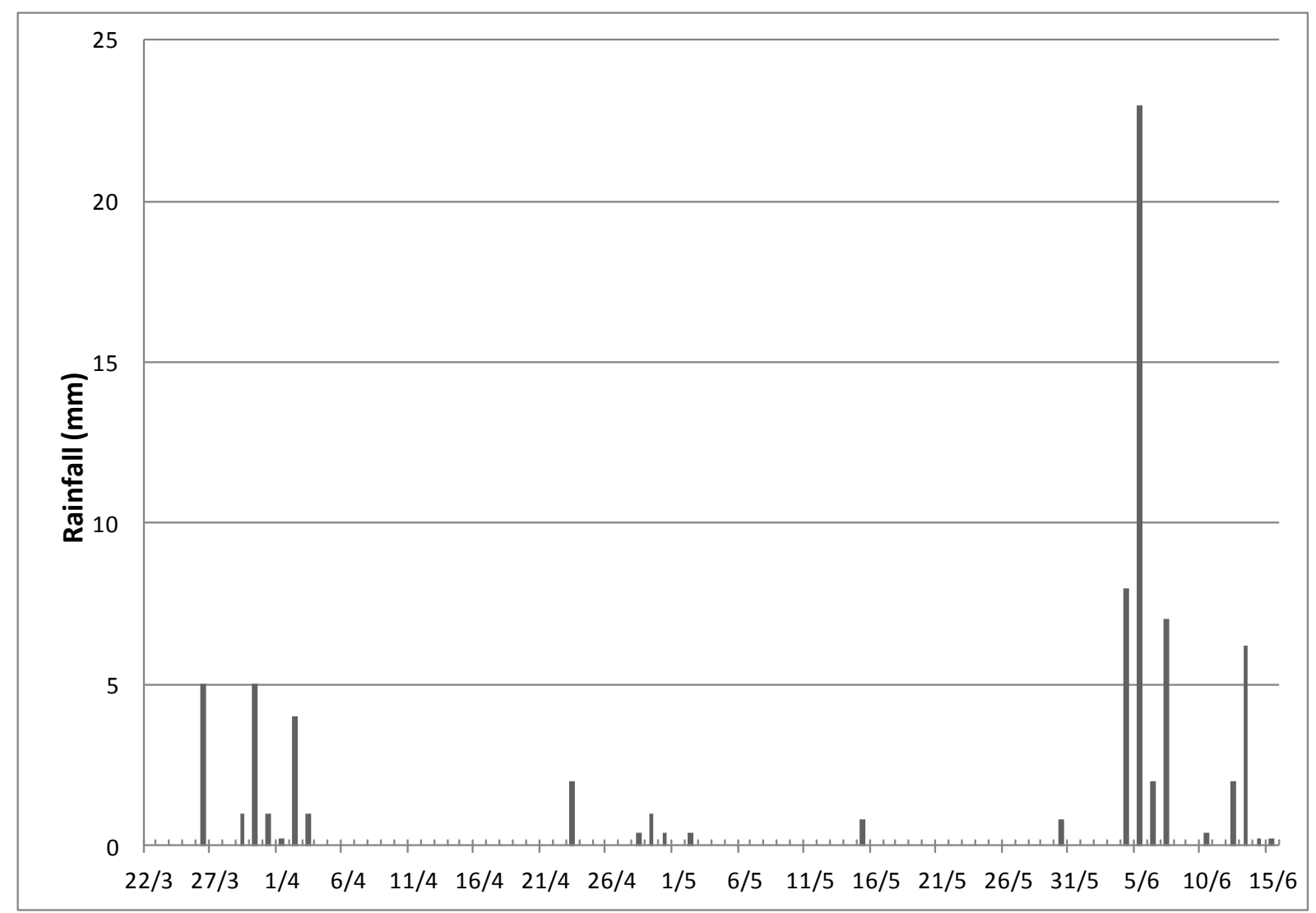


Table 1.

${ }^{131} \mathrm{I},{ }^{137} \mathrm{Cs}$ and ${ }^{134} \mathrm{Cs}$ activities $\left(\mu \mathrm{Bq} \mathrm{m}{ }^{-3}\right)$ determined in the filters collected on top of Pic $d u$ Midi, French Pyrénées. The uncertainties are onesigma error associated with counting statistics.

\begin{tabular}{|c|c|c|c|c|c|}
\hline Sample & Sampling period & ${ }^{131} \mathrm{I}$ & ${ }^{7} \mathrm{Be}$ & ${ }^{137} \mathrm{Cs}$ & ${ }^{134} \mathrm{Cs}$ \\
\hline \# 123 & $15 / 3-22 / 3$ & $<$ MDA & $1620 \pm 40$ & $<\mathrm{MDA}$ & $<\mathrm{MDA}$ \\
\hline \# 124 & $22 / 3-29 / 3$ & $200 \pm 6$ & $1650 \pm 30$ & $<\mathrm{MDA}$ & $<$ MDA \\
\hline \# 125 & $29 / 3-5 / 4$ & $<\mathrm{MDA} *$ & $1490 \pm 60$ & $10 \pm 2$ & $7 \pm 2$ \\
\hline \# 126 & $5 / 4-12 / 4$ & $<\mathrm{MDA} *$ & $2890 \pm 80$ & $<\mathrm{MDA}$ & $<\mathrm{MDA}$ \\
\hline \# 127 & $12 / 4-19 / 4$ & $<\mathrm{MDA} *$ & $2160 \pm 70$ & $<\mathrm{MDA}$ & $<\mathrm{MDA}$ \\
\hline \# 128 & $19 / 4-26 / 4$ & $<\mathrm{MDA} *$ & $1470 \pm 50$ & $<\mathrm{MDA}$ & $<\mathrm{MDA}$ \\
\hline
\end{tabular}

MDA : Minimum Detectable Activity $\left(<10 \mu \mathrm{Bq} \mathrm{m}{ }^{-3}\right.$ for ${ }^{131} \mathrm{I} ;<4 \mu \mathrm{Bq} \mathrm{m}$. for ${ }^{137} \mathrm{Cs}$ and ${ }^{134} \mathrm{Cs}$; given at 2-sigma level).

* These samples were analyzed several weeks after sample collection, which prevented the potential detection of ${ }^{131}$ I activities. 
Table 2.

Fission product radionuclide activity $\left(\mathrm{Bq} \mathrm{kg}^{-1}\right)$ in grass samples collected in the Parisian Region between 30 March and 14 June, 2011.

\begin{tabular}{|c|c|c|c|c|c|c|c|c|}
\hline Sampling date & Sampling site & ${ }^{131} \mathrm{I}$ & ${ }^{134} \mathrm{Cs}$ & ${ }^{137} \mathrm{Cs}$ & ${ }^{137} \mathrm{Cs} /{ }^{134} \mathrm{Cs}$ & ${ }^{131} \mathrm{I} /{ }^{137} \mathrm{Cs}$ & ${ }^{131} \mathrm{I} /{ }^{134} \mathrm{Cs}$ & ${ }^{7} \mathrm{Be}$ \\
\hline \multirow[t]{4}{*}{$30 / 03 / 2011$} & Les Avenelles & $<3.6$ & $<2.5$ & $<2.5$ & & & & $45 \pm 10$ \\
\hline & Mélarchez & $4.3 \pm 1.4$ & $<2.9$ & $<2.9$ & & & & $140 \pm 20$ \\
\hline & La Loge & $4.0 \pm 0.6$ & $<1.0$ & $<1.1$ & & & & $140 \pm 10$ \\
\hline & Le Theil & $2.9 \pm 0.4$ & $<0.7$ & $<0.8$ & & & & $15 \pm 5$ \\
\hline $31 / 03 / 2011$ & Gif-s/Yvette & $6.6 \pm 0.4$ & $1.3 \pm 0.3$ & $0.9 \pm 0.3$ & $0.7 \pm 0.4$ & $7.3 \pm 2.9$ & $5.1 \pm 1.5$ & $90 \pm 5$ \\
\hline 05/04/2011 & Palaiseau & $11.0 \pm 1.0$ & $1.6 \pm 0.4$ & $1.2 \pm 0.4$ & $0.7 \pm 0.4$ & $9.0 \pm 3.8$ & $6.9 \pm 2.3$ & $170 \pm 5$ \\
\hline 09/04/2011 & Fontenay-les-Briis & $1.7 \pm 0.1$ & $0.2 \pm 0.1$ & $1.0 \pm 0.1$ & $5.0 \pm 3.0$ & $1.7 \pm 0.3$ & $8.5 \pm 4.8$ & $35 \pm 5$ \\
\hline $10 / 04 / 2011$ & Limours & $4.5 \pm 0.4$ & $1.4 \pm 0.3$ & $1.6 \pm 0.3$ & $1.1 \pm 0.4$ & $2.8 \pm 0.8$ & $3.2 \pm 1.0$ & $55 \pm 5$ \\
\hline \multirow[t]{2}{*}{$28 / 04 / 2011$} & Mélarchez & $<0.2$ & $<0.1$ & $<0.1$ & & & & $10 \pm 5$ \\
\hline & Le Theil & $<0.2$ & $<0.1$ & $<0.1$ & & & & $10 \pm 5$ \\
\hline \multirow[t]{2}{*}{$14 / 06 / 2011$} & Mélarchez & $<0.3$ & $<0.2$ & $<0.2$ & & & & $30 \pm 5$ \\
\hline & Le Theil & $<0.1$ & $<0.1$ & $<0.1$ & & & & $25 \pm 5$ \\
\hline
\end{tabular}


Table 3.

Fission product radionuclide activity $\left(\mathrm{Bq} \mathrm{kg}^{-1}\right)$ in soil and sediment samples collected in the Seine River basin between 16 March and 14 June, 2011. The error values shown are 2-sigma uncertainties.

\begin{tabular}{|c|c|c|c|c|c|c|c|c|}
\hline Sampling date & Sampling site/matrix & ${ }^{131} \mathrm{I}$ & ${ }^{134} \mathrm{Cs}$ & ${ }^{137} \mathrm{Cs}$ & ${ }^{131} \mathrm{I} /{ }^{137} \mathrm{Cs}$ & ${ }^{210} \mathrm{~Pb}_{\mathrm{xs}}$ & ${ }^{7} \mathrm{Be}$ & ${ }^{7} \mathrm{Be} /{ }^{210} \mathrm{~Pb}_{\mathrm{xs}}$ \\
\hline \multirow[t]{3}{*}{$30 / 03 / 2011$} & La Loge (soil) & $<0.2$ & $<0.2$ & $3.2 \pm 0.1$ & & $10 \pm 1$ & $5 \pm 1$ & $0.5 \pm 0.2$ \\
\hline & Mélarchez (soil) & $0.4 \pm 0.1$ & $<0.2$ & $1.6 \pm 0.1$ & $0.2 \pm 0.1$ & $10 \pm 1$ & $10 \pm 1$ & $1.0 \pm 0.2$ \\
\hline & Mélarchez (sediment) & $4.5 \pm 1.7$ & $<2.2$ & $6.0 \pm 0.6$ & $0.7 \pm 0.3$ & $50 \pm 5$ & $55 \pm 5$ & $1.1 \pm 0.2$ \\
\hline \multirow[t]{3}{*}{$12 / 04 / 2011$} & Grange Allard (sediment) & $60 \pm 30$ & $<2.7$ & $3.6 \pm 0.8$ & $15 \pm 11$ & $30 \pm 5$ & $70 \pm 10$ & $2.3 \pm 0.7$ \\
\hline & Ribeaucourt (sediment) & $<50$ & $<4.3$ & $6.4 \pm 1.2$ & & $60 \pm 10$ & $110 \pm 10$ & $1.8 \pm 0.5$ \\
\hline & Vitry-le-François (sediment) & $<50$ & $<2.9$ & $6.1 \pm 0.8$ & & $90 \pm 10$ & $45 \pm 10$ & $0.5 \pm 0.2$ \\
\hline $28 / 04 / 2011$ & Mélarchez (sediment) & $<44$ & $<1.2$ & $3.8 \pm 0.7$ & & $35 \pm 5$ & $55 \pm 5$ & $1.6 \pm 0.4$ \\
\hline $17 / 05 / 2011$ & Mélarchez (sediment) & $<44$ & $<2.2$ & $6.0 \pm 0.7$ & & $50 \pm 5$ & $55 \pm 5$ & $1.1 \pm 0.2$ \\
\hline \multirow[t]{3}{*}{ 07/06/2011 } & Grange Allard (sediment) & $<57$ & $<3.1$ & $3.3 \pm 0.8$ & & $50 \pm 10$ & $160 \pm 10$ & $3.2 \pm 0.8$ \\
\hline & Ribeaucourt (sediment) & $<3$ & $<0.8$ & $8.0 \pm 0.6$ & & $75 \pm 5$ & $160 \pm 5$ & $2.1 \pm 0.2$ \\
\hline & Vitry-le-François (sediment) & $<13$ & $<2.7$ & $2.2 \pm 0.7$ & & $35 \pm 10$ & $75 \pm 5$ & $2.1 \pm 0.8$ \\
\hline $14 / 06 / 2011$ & Mélarchez (sediment) & $<21$ & $<2.2$ & $1.2 \pm 0.4$ & & $20 \pm 5$ & $35 \pm 5$ & $1.8 \pm 0.7$ \\
\hline
\end{tabular}

